\title{
Problems in Western Economics Teaching and Countermeasures
}

\author{
Hou Yunhui \\ Weinan Normal University, Weinan, Shaanxi, 714099
}

Keywords: Western economics; teaching; problem analysis; countermeasures

\begin{abstract}
Western economics is a product of the development of the market economy to a certain extent. In China, Western economics was introduced as early as during the May 4th movement. However, it did not become a core course of economics and management in colleges and universities after the reform and opening up. In the era of economic globalization, the teaching objectives and requirements of Western economics have undergone great changes compared with the previous ones. They emphasize that Western economics not only provides language, technology and proposition but also provides multidimensional perspectives and ideas. It shows the theoretical framework of neoclassical economics and trains student's way of thinking in economics. However, in the actual teaching process, there are still many problems in the western economics in colleges and universities. In face of these problems, the paper put forward corresponding solutions so as to improve the teaching effectiveness of western economics. It mainly analyzes and sums up the existing problems in Western economics teaching at present stage. And it puts forward concrete solutions in order to provide a reference for Western economics teaching practice.
\end{abstract}

\section{Features of Western economics course}

Compared with other courses, western economics course reflects the following characteristics:

First, the comprehensive features. The course of western economics consists of the economic theories of the mainstream schools [1]. Its theoretical system is comprehensive and its teaching contents cover a wide range of topics, including three parts: microeconomics, macroeconomics and major schools of economics. Among them, microeconomics mainly studies the theory of price. Its research object focuses on a single consumer and producer. Macroeconomics mainly studies the theory of national income [2]. Its research object focuses on the overall national economy activities as a whole. The main schools of economics include neoclassical economics, Keynesian economics, new Keynesian school, neoclassical macroeconomic school and so on. The theoretical system of Western economics is very rich. Comprehensive features are very prominent. Second, it involves more disciplines and research methods [3]. Western economics and mathematics, statistics, finance, finance, sociology, management and other disciplines are closely related. And the cross-cutting disciplines derived such as information economics, behavioral economics and some new edge discipline. And emerging disciplines continue to enrich the theoretical system of Western economics [4-5]. In the course of the study of western economics, both the normative analysis and the empirical analysis contain not only abstract analysis but also concrete descriptions. The research methods are diversified. The basic theories are usually written in words, geometric figures, mathematical models and other forms of performance [6]. They involve more subjects, research methods and more features to increase the difficulty of learning for beginners. The main research content of economics is to study the economic behavior, the result of the behavior and the whole process of "economic man" in a series of social activities. Therefore, the formation of research on the production and consumption exchanges the "economic man" [7].

\section{Problems in Western economics teaching}

Specifically, the western economics teaching at the present stage still has the following problems: 


\subsection{Mismatch between the textbook compilation and the actual situation}

Textbook writing mainly has the following questions: first of all, the teaching material theoretical knowledge and the reality of China's economic development are inconsistent. Western economics teaching at this stage is still used in traditional economics textbooks [8]. The content of knowledge is mainly based on microeconomic theory and the macroeconomic theory is based on large-scale industrial production in western countries. Many theories do not match or even run counter to China's reality. Leading teachers and students are confused in the process of teaching and learning, they are practicality greatly reduced. Second, the specialization of teaching materials is too strong. Most of the current teaching materials are special textbooks for economy and management major, which are of theoretical significance. This is of some positive significance for perfecting the knowledge system of students. However, it is lack of professional basic knowledge required for such majors, such as mathematical models, history of economic theory and history of economic thought. It leads to confusion in learning. Learning enthusiasm is not high. Therefore, it affects the teacher's teaching enthusiasm. Finally, the lack of practical knowledge is existed in teaching materials. With the transformation from talent elitism to popularization, the goal of personnel training in colleges and universities has gradually shifted to the cultivation of applied talents. No matter which practical knowledge of professional life is more close to the actual life of students. Entrepreneurship education and other knowledge are more attractive to college students. The application of knowledge of the economic activities in life can give guidance to increase students' learning identity, such as rational consumption, rational investment, innovation and entrepreneurship and so on [9]. However, the existing teaching materials of western economics weaken the practicability of knowledge. It is lack of practical application and education concept of undertaking employment. It is hard to adapt to the development of the times and not conducive to the goal of talent cultivation.

\subsection{Errors in the application of multimedia technology}

With the development of information technology, the application of multimedia in the teaching field is becoming more and more popular. Multimedia technology concentrates on various forms such as text, graphics, sound, animation and video, which improves teaching efficiency and effectiveness and makes the abstract knowledge more specific. It improves the expressiveness of teaching content. However, as an auxiliary teaching method, multimedia technology can not completely replace the traditional teaching methods. However, the actual situation is that some teachers rely more and more on multimedia courseware. Many of the knowledge presented through multimedia courseware is actually another in the sense of "copybook". Western economics contains a large number of mathematical reasoning and graphic analysis. Simply presenting this knowledge through multimedia courseware is of little help to students' understanding. In mathematical reasoning and graphic analysis, teachers still need to use traditional teaching methods, such as writing on a blackboard. So over-reliance on multimedia courseware will affect the teacher's teaching ideas and lead to its logic chaos. And ultimately they affect their teaching effectiveness [10].

\subsection{The evaluation method is not objective enough}

At this stage, many colleges and universities western economics curriculum evaluation mostly adopt the final examination system, but the main object of economics is the economic main body behavior and result, so it emphasizes the application of the discipline. However, the final exams and the usual credit system cannot fully reflect the ability of students. One paper and two hours' time are not enough objective and comprehensive theoretical results to reflect the true level of students. Many students take a clumsy study of some theories Knowledge rote memorization, making the role of the evaluation mechanism is not effective. Now many school exam questions are questions by using the exam questions. It is unable to highlight the key points. In order to allow students to improve the test scores, some teachers require students to be involved in teaching. The content of the outline should be understood that all the questions in the library should be mastered. This lack 
of prominence not only increases students 'learning burden, but also it is not conducive to students' ability to analyze and solve problems. However, there are two reasons why teachers should not focus on lectures. First, teachers are not sufficiently prepared lessons due to their limited knowledge. Second, there are fewer lectures in microeconomics and macroeconomics. Because the knowledge of western economics is more and more abstract less time cannot help students to better understand the point of knowledge. Due to the limited class hours, the teacher can only explain more important and difficult knowledge in a short time, which makes it difficult for the teacher to make a clear evaluation of the key points in the evaluation process and eventually reduces the utility of the evaluation.

\section{Strategies to improve the effectiveness of Western economics teaching}

In view of the existing problems in western economics teaching, it is suggested to improve from the following aspects:

\subsection{Reform of Western economics textbooks}

Teaching material is an important medium for teaching activities between teachers and students. Therefore, we must reform the existing teaching materials of western economics according to the principle of "basic, applied and practical". It is necessary to emphasize the basic concepts and basic theory of the elaboration and interpretation, but also highlight the practical application of knowledge. For example, the price elasticity of demand can omit the limit derivation process. It simply introduces the elastic formula and simple calculation method. For another example, when introducing the production function of a manufacturer, labor input shows that this approach is not practical for students who have never been to the factory. In response to this problem, the analysis of farmland and labor in farmland cultivation can be replaced with the replacement of capital and labor in factory production to deepen students' understanding. For another example, the introduction of macroeconomics to monetary theory and employment theory is too complicated. In view of this situation, it is possible to increase the number of students according to the actual economic development in our country Interests, such as consumer finance, student entrepreneurship, examinations and other content to stimulate student enthusiasm for learning and improve teaching effectiveness.

\subsection{To achieve the traditional combination of teaching and modern teaching methods}

Multimedia technology is an effective aid to the traditional teaching of western economics, which can improve the teaching efficiency and teaching effect. However, it must be applied reasonably to avoid entering the overriding misunderstandings. The actual teaching should realize the organic combination of traditional teaching and multimedia technology. The use of multimedia means sorts out the theoretical system of Western Economics into a complete framework. The process of explaining the use of traditional means is interspersed with the corresponding statistical data, graphics and mathematical deduction. They not only can improve the vividness of classroom teaching, but also the image can be reflected the systematic knowledge of Western economics. Facing the limitations of multimedia technology, the modern means of online teaching and traditional teaching organically together are employed. The campus teaching network platform is employed to share Western economics courseware and even non-economics students can also download, apply and improve knowledge sharing. In addition, students can communicate and exchange with teachers through the network platform in order to achieve the effect of teaching simultaneously and human-computer interaction.

\subsection{Reform teaching evaluation method}

Teachers should change their concepts and cannot regard test scores as the only criterion for evaluating students' learning effectiveness. They should overcome the problem of using test questions libraries as teaching orientation so that students no longer have to memorize rote. Western economics assessment can be divided into theoretical knowledge assessment and comprehensive 
application of ability assessment of two aspects. The test of theoretical knowledge is still based on the test question bank, but it should be highlighted. The assessment of comprehensive application ability can be done by writing economics essay and case analysis. The teacher can divide the students into several discussion groups. Each group member has a clear division of labor, collecting data, designing questionnaires, writing essays and so on. The completion of the thesis, the level of participation, all kinds of reports are submitted to comprehensive evaluation of student achievement. Case analysis is used to determine the theme by the students themselves through a variety of ways to collect information. They submit a case analysis report. This assessment cannot only understand the students grasp the basic concepts, but also it is used to examine its comprehensive ability.

\section{Conclusions}

In short, western economics is a basic course and a core course that are universally established in economics and management of colleges and universities in our country. It plays a great role in promoting the dissemination and study of western economic theory. And it helps students to understand more comprehensively foreign advanced ideas and theories to expand their horizons. Of course, we must face up to the problems existing in western economics teaching at present. For example, the applicability of teaching materials is not strong. The evaluation method is single and the teaching methods are misunderstood. The existence of these problems will directly affect the teaching effect. Therefore, in the actual teaching process, we should clarify the teaching objectives and strengthen the reform of teaching materials. It improves the curriculum evaluation methods and improves the teaching effectiveness of Western economics.

\section{References}

[1] Gao Hongye. Western Economics (Micro Section) (Fourth Edition) [M]. China People's Publishing House, 2008.

[2] Yue Aixian. Western economics teaching multimedia teaching methods used [J]. Journal of Nanchang Institute of Education [J], 2016 (4): 42-44

[3] Zou Yun. Western economics course teaching reform [J]. Henan Commercial College Journal [J], 2017 (6): 114-117

[4] Zhu Guangqi. Reflections on the Teaching Reform of Western Economics under the Background of Work-study Combination [J]. Journal of Shandong Business Technology Institute, 2014 (6): 64-67

[5] Shu Yan. On the problems and countermeasures in the course of western economics teaching [J]. Journal of Higher Education Research, 2016 (2): 62-64.

[6] Xu Ting. Experimental teaching of liberal arts in universities [J]. Experimental Technology and Management, 2016 (10): 106.

[7] Ma Huijing. Reform of Economics Experimental Teaching Method [J]. Journal of Hebei Radio \& TV University, 2017 (6): 58.

[8] Duan Pengfei. On the economics of classroom experimental teaching method [J]. Dongbei University of Finance and Economics, 2015 (6): 76.

[9] Xu Jishun. Exploration and Practice of Experimental Teaching of Liberal Arts in Universities [J]. Journal of Southwest University for Nationalities, 2014 (7): 332.

[10] Chen Sihui, Yang Xihong. Inheritance and Transcendence --- Exploration of Western Economics Teaching Reform [J]. Journal of Chengdu University, 2017 (3): 78-80 